\title{
Miocene Jiali faulting and its implications for Tibetan tectonic evolution
}

\author{
Hao-Yang Lee ${ }^{a}$, Sun-Lin Chung ${ }^{a}{ }^{*}$, Jun-Ren Wang ${ }^{a}$, Da-Jen Wen ${ }^{a}$, Ching- \\ Hua Lo ${ }^{a}$, Tsanyao F. Yang ${ }^{a}$, Yuquan Zhang ${ }^{b}$, Yingwen Xie ${ }^{b}$, Tung-Yi Lee ${ }^{c}$, \\ Genyao $\mathrm{Wu}^{\mathrm{d}}$, Jianqing $\mathrm{Ji}^{\mathrm{e}}$ \\ a Department of Geosciences, National Taiwan University, Taipei, Taiwan \\ b Guangzhou Institute of Geochemistry, Chinese Academy of Sciences, Guangzhou, PR China \\ c Department of Earth Sciences, National Taiwan Normal University, Taipei, Taiwan \\ $\mathrm{d}$ Institute of Geology and Geophysics, Chinese Academy of Sciences, Beijing, PR China \\ e Department of Geology, Peking University, Beijing, PR China
}

Received 22 July 2002; received in revised form 18 October 2002; accepted 20 October 2002

\begin{abstract}
The Karakoram-Jiali Fault Zone (KJFZ) comprises a series of right-lateral shear zones that southerly bound the eastward extrusion of northern Tibet relative to India and stable Eurasia. Here we present new ${ }^{40} \mathrm{Ar} /{ }^{39} \mathrm{Ar}$ age data from the Puqu and Parlung faults, two easternmost branches of the Jiali fault zone, which indicate a main phase of the KJFZ shearing from $\sim 18$ to $12 \mathrm{Ma}$. Thus, the Tibetan eastward extrusion bounded by principal strike-slip fault zones started and was probably most active around the middle Miocene, an interval marked also by active east-west extension in southern Tibet. The coincidence of these two tectonic events strongly suggests a common causal mechanism, which is best explained as oblique convergence between India and Asia. Under the framework of this mechanism, the extension in southern Tibet is not a proxy for the plateau uplift. The KJFZ activity was furthermore coincident with right-lateral displacements along the Gaoligong and Sagaing faults in southeast Asia. This defines a Miocene deformation record for the regional dextral accommodation zone that, in response to the continuing IndiaAsia collision, may have accounted for the initiation and prolonged history of clockwise rotation of the Tibetan extrusion around the eastern Himalayan Syntaxis.
\end{abstract}

(C) 2002 Elsevier Science B.V. All rights reserved.

Keywords: Karakoram-Jiali fault zone; Tibet; eastern Himalayan Syntaxis; Ar-40/Ar-39 dating

\section{Introduction}

Two end-member models of how the high elevations of the Tibetan plateau formed by the continuing northward indentation of India into Asia

* Corresponding author. Tel.: +886-2-8369 1242; Fax: +886-2-2363 6095 .

E-mail address: sunlin@ccms.ntu.edu.tw (S.-L. Chung). are (i) homogeneous thickening and subsequent convective thinning of the Tibetan lithosphere 
[1,2] and (ii) episodic block extrusion away from the indenting Indian plate along principal strikeslip shear zones $[3,4]$. These lead to further controversies on whether the east-west extension prevailing in the Himalayas and southern Tibet [5] is related to the plateau's uplift and associated potassic magmatism caused by lithospheric thinning $[1,2,6-9]$, or to the accommodation of regional boundary forces $[3-5,10,11]$. To test the above models and better understand the tectonic evolution of the Himalayan-Tibetan orogen, we report new ${ }^{40} \mathrm{Ar} /{ }^{39} \mathrm{Ar}$ dating results from the easternmost branches of the dextral Jiali fault zone around the eastern Himalayan Syntaxis (Fig. 1). Our data suggest that the Jiali fault zone was active in middle Miocene time. This study provides an important time constraint that enables us to explore not only the relationship between the strike-slip faulting and east-west extension in southern Tibet but also some orogen-wide tectonic implications such as when and how the Tibetan eastward extrusion started.

\section{Background}

In southern Tibet, a mixture of normal and strike-slip faulting has been described to characterize the active tectonics of this region [3$5,11,12]$. The normal faults, striking north-south (Fig. 1b) and hence reflecting east-west extension, are widespread despite the fact that the Indian plate is moving northward relative to stable Eurasia at a rate of $\sim 4 \mathrm{~cm} / \mathrm{yr}$ [13]. Whereas some ${ }^{40} \mathrm{Ar} /{ }^{39} \mathrm{Ar}$ dating studies [7,9] suggested that the normal faulting began and was most active during $\sim 18-13 \mathrm{Ma}$, its activity may have further intensified at $\sim 8 \mathrm{Ma}[11]$ and lasted to the present $[5,14]$. The strike-slip fault system is represented by the Karakoram-Jiali Fault Zone (KJFZ) [12], consisting of a set of NW-SE aligned, right-lateral faults (Fig. 1b) that appear to terminate the northern tips of the normal fault system in southern Tibet. ${ }^{40} \mathrm{Ar} /{ }^{39} \mathrm{Ar}$ dating and geological data $[15,16]$ showed that the displacement along the Karakoram fault started at $\sim 17 \mathrm{Ma}$, and that metamorphic rocks within the fault zone underwent two episodes of rapid exhumation via dex- tral oblique thrusting during $\sim 17-13$ and $\sim 8-7$ Ma, respectively.

The KJFZ is bounded by the Jiali fault zone in the east. To the southeast, it splays into two major branches, namely the Puqu and Parlung faults, which extend toward the eastern margin of the Himalayan Syntaxis (Fig. 1). The Jiali fault, affiliated with the great $(M=8.7)$ Assam (or Chayu) earthquake of August 15, 1950 [14], is likely to be the most prominent active fault located north of the Himalayan Syntaxis [12]. Similar to the Karakoram fault, its movement was probably characterized by a combination of dextral strike-slip and thrust components as revealed by earthquake focal mechanism analyses [12,14]. Precise radiometric age data were not available along the Jiali fault. Although records of its late Tertiary activity have been presumed in several localities, it was the Quaternary displacement that was emphasized in the previous work [12]. In this study, we collected samples from the Puqu and Parlung faults via a northeast-southwest transverse (Fig. 1), which crosscuts the easternmost part of the Gangdese Batholith representing an Andean-type magmatic arc along the Asian continental margin in the Lhasa block that resulted from northward subduction of the NeoTethyan slab before the Indian collision with Asia [17]. Along this transverse (Fig. 2), intensively sheared granitic rocks marked by gneissic or mylonitic structure indicating a dominant dextral movement are exposed. The rocks often contain garnet and/or sillimanite, with peak metamorphic temperatures and pressures estimated to be $\geq$ $550^{\circ} \mathrm{C}$ and $\sim 3-5 \mathrm{kbar}$, respectively [18]. Five such samples from the Puqu and three from the Parlung faults (Fig. 2) were used for geochronological analysis in the hope of constraining the timing of the shearing activity.

\section{Analytical results}

Mineral separates of amphibole, biotite and K-feldspar were dated by ${ }^{40} \mathrm{Ar} /{ }^{39} \mathrm{Ar}$ step-heating techniques. All results and brief analytical procedures are summarized in Table 1, and detailed experimental results are given in the Background 

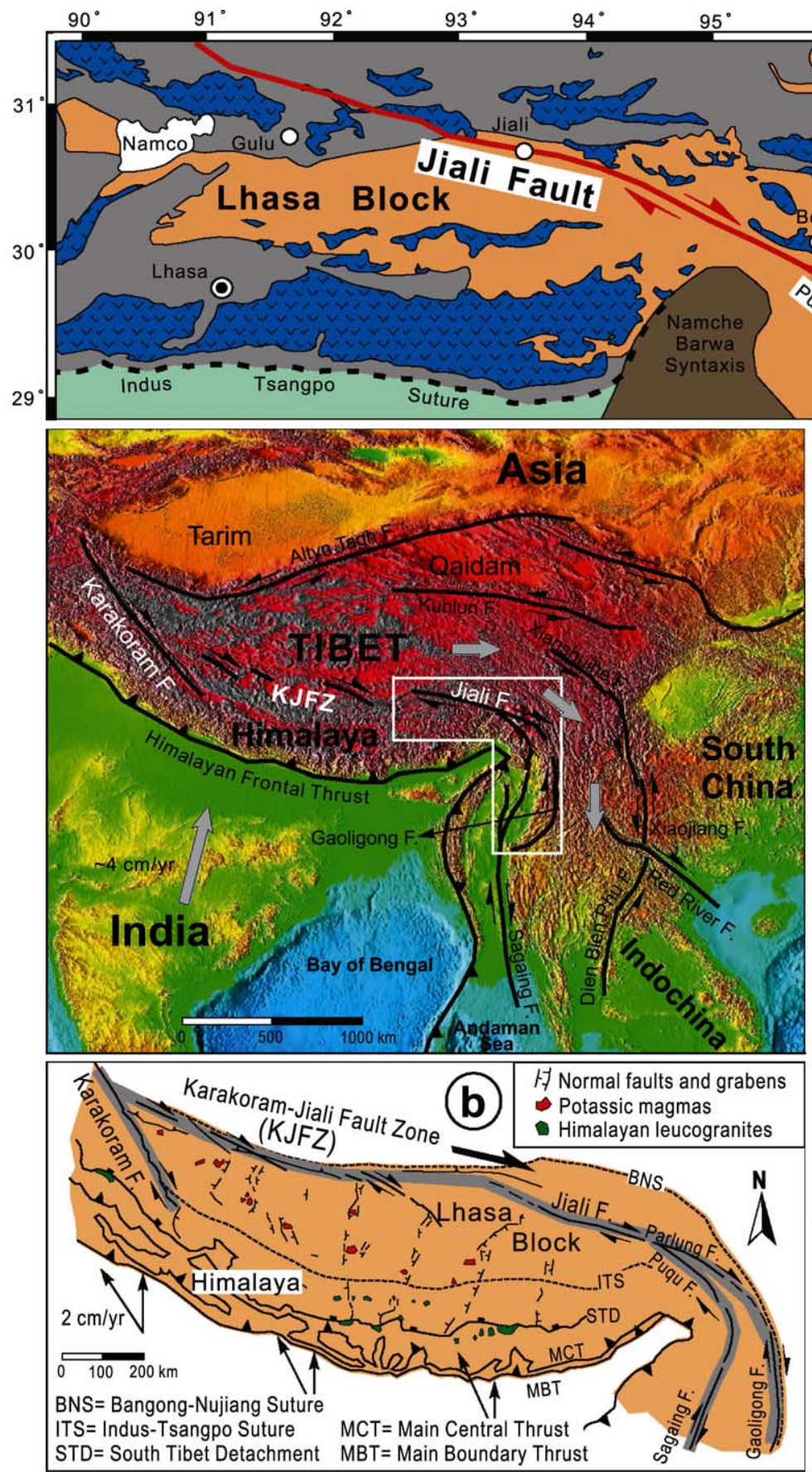
$96^{\circ}$ $97^{\circ}$ $98^{\circ}$ $2^{31^{\circ}}$ 

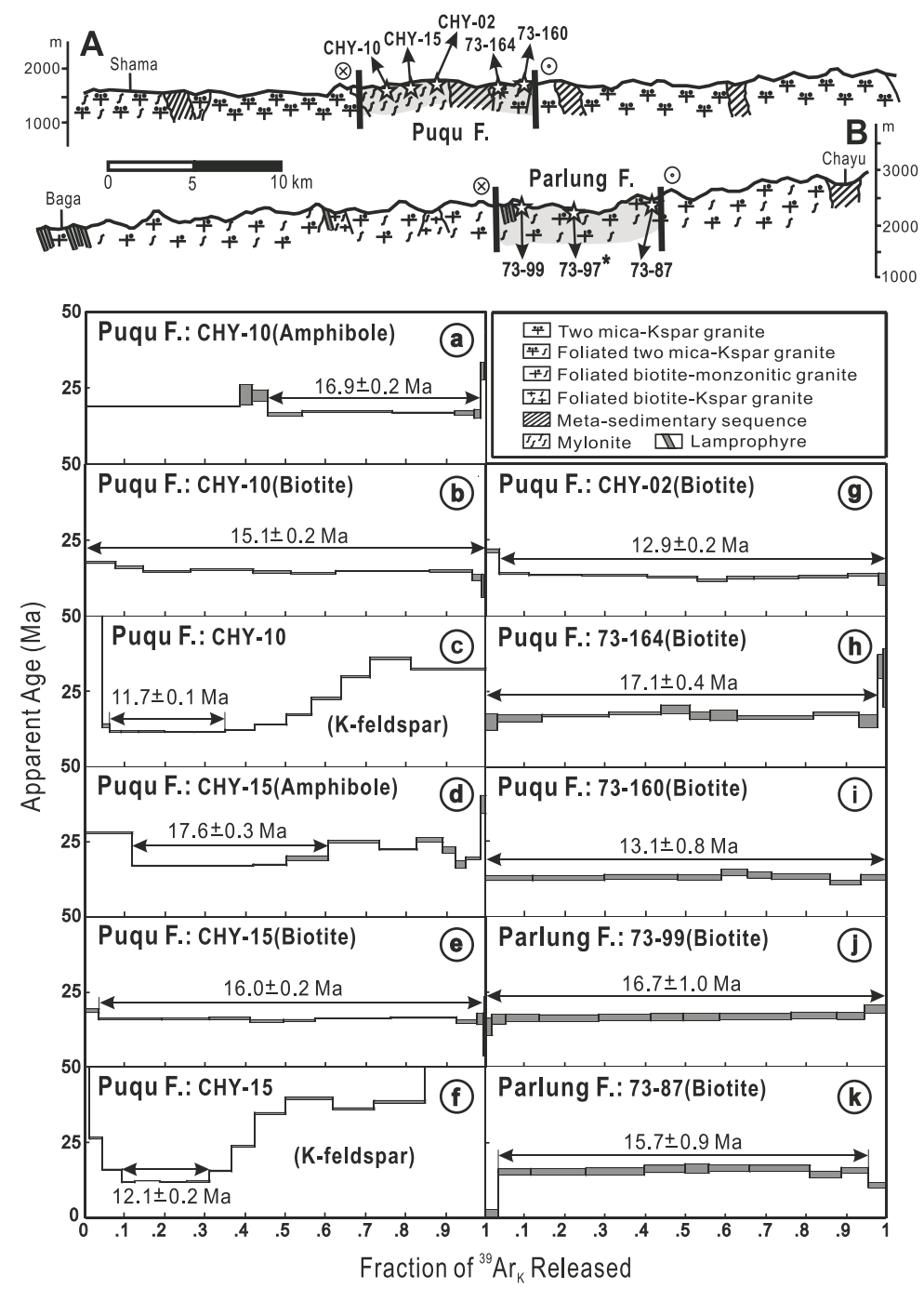

Fig. 2. Schematic profile across the Puqu and Parlung faults from which mylonites and sheared granites were recovered for zircon $\mathrm{U}-\mathrm{Pb}$ (\#73-97) and ${ }^{40} \mathrm{Ar} /{ }^{39} \mathrm{Ar}$ dating analyses. The profile cuts the eastern Gangdese complex and carboniferous meta-sedimentary sequences. Mylonitic granites within the Puqu fault were previously termed 'migmatites' by local geologists. In some localities, lamprophyre dikes occur in association with felsic pegmatites and show dominant foliations striking $\sim 220-230^{\circ} \mathrm{E}$, corresponding to those observed in the mylonites and sheared granites. (a-k) ${ }^{40} \mathrm{Ar} /{ }^{39} \mathrm{Ar}$ age spectra obtained by the step-heating method. Plateau dates were calculated within arrows, which indicate the Ar fractions used. The vertical height of each step represents $2 \sigma$ intra-laboratory error. All analytical errors shown are $1 \sigma$ values that include uncertainties derived from the age of the standard (LP-6 Biotite). Amp= amphibole; $\mathrm{Bt}=$ biotite; Ksp = K-feldspar.

Data Set $^{1}$. These results are presented in the age spectrum diagrams (Fig. 2a-k), with sample localities in the transverse profile. To examine possible disturbances of the Ar system, a ${ }^{36} \mathrm{Ar} /{ }^{40} \mathrm{Ar}$ vs.

\footnotetext{
${ }^{1}$ http://www.elsevier.com/locate/epsl
}

${ }^{39} \mathrm{Ar} /{ }^{40} \mathrm{Ar}$ relationship for each mineral phase was performed (also given in the Background Data Set ${ }^{1}$ ). These examinations yielded the intercept dates, initial ratios of ${ }^{40} \mathrm{Ar} /{ }^{36} \mathrm{Ar}$ and values of mean square weighted deviates (MSWD) listed in Table 1. In Fig. 2, all biotite separates show flat age spectra, which yield plateau dates ranging 
Table 1

Summary of ${ }^{40} \mathrm{Ar} /{ }^{39} \mathrm{Ar}$ dating results for the eastern Gangdese granitoids

\begin{tabular}{|c|c|c|c|c|c|c|c|c|}
\hline Sample & Rock type & Phase dated & $\begin{array}{l}\text { Plateau date } \\
(M y r \pm \sigma)\end{array}$ & $\begin{array}{l}N \\
\text { (steps) }\end{array}$ & $\begin{array}{l}{ }^{39} \mathrm{Ar} \text { proportion } \\
(\%)\end{array}$ & $\begin{array}{l}\text { Intercept date } \\
(\operatorname{Myr} \pm \sigma)\end{array}$ & $\begin{array}{l}\left({ }^{40} \mathrm{Ar} /{ }^{36} \mathrm{Ar}\right)_{\mathrm{i}} \\
( \pm \sigma)\end{array}$ & MSWD \\
\hline \multicolumn{9}{|c|}{ Puqu Fault } \\
\hline \multirow[t]{3}{*}{ CHY-10 } & Mylonite & Amphibole & $16.9 \pm 0.2$ & 5 & 53.0 & $16.9 \pm 0.3$ & $305 \pm 45$ & 1.112 \\
\hline & Mylonite & Biotite & $15.1 \pm 0.2$ & 10 & 99.7 & $14.9 \pm 0.2$ & $321 \pm 3$ & 2.219 \\
\hline & Mylonite & K-feldspar & $11.7 \pm 0.1^{\mathrm{a}}$ & 5 & 29.0 & $11.7 \pm 0.1$ & $311 \pm 54$ & 0.823 \\
\hline \multirow[t]{3}{*}{ CHY-15 } & Mylonite & Amphibole & $17.6 \pm 0.3$ & 3 & 48.8 & $16.9 \pm 0.5$ & $336 \pm 22$ & 2.400 \\
\hline & Mylonite & Biotite & $16.0 \pm 0.2$ & 9 & 96.2 & $16.1 \pm 0.2$ & $287 \pm 6$ & 1.528 \\
\hline & Mylonite & K-feldspar & $12.1 \pm 0.2^{\mathrm{a}}$ & 4 & 22.0 & $11.8 \pm 0.4$ & $321 \pm 29$ & 2.483 \\
\hline CHY-02 & Mylonite & Biotite & $12.9 \pm 0.2$ & 10 & 96.6 & $12.9 \pm 0.3$ & $326 \pm 12$ & 1.689 \\
\hline $73-160$ & $\begin{array}{l}\text { Foliated } \\
\text { granite }\end{array}$ & Biotite & $13.1 \pm 0.8$ & 9 & 100 & $13.2 \pm 1.2$ & $288 \pm 78$ & 0.903 \\
\hline $73-164$ & $\begin{array}{l}\text { Foliated } \\
\text { granite }\end{array}$ & Biotite & $17.1 \pm 0.4$ & 10 & 97.8 & $17.5 \pm 0.5$ & $284 \pm 24$ & 1.073 \\
\hline \multicolumn{9}{|c|}{ Parlung Fault } \\
\hline $73-870$ & $\begin{array}{l}\text { Foliated } \\
\text { granite }\end{array}$ & Biotite & $15.7 \pm 0.9$ & 9 & 92.6 & $15.4 \pm 1.1$ & $296 \pm 158$ & 0.735 \\
\hline $73-990$ & $\begin{array}{l}\text { Foliated } \\
\text { granite }\end{array}$ & Biotite & $16.7 \pm 1.0$ & 11 & 100 & $16.9 \pm 1.1$ & $290 \pm 32$ & 1.253 \\
\hline
\end{tabular}

The mineral grains, handpicked and sieved to the size range of $140-250 \mu \mathrm{m}$, were ultrasonically cleaned in distilled water and dried, and then irradiated in the THOR Reactor at National Tsing-Hua University in Taiwan. To monitor the neutron flux, aliquots of the LP-6 biotite standard (128.4 $\pm 0.2 \mathrm{Ma})$ [45], weighing $\sim 6-10 \mathrm{mg}$ [46], were stacked with the samples. After irradiation, the standards and samples were heated incrementally using a double-vacuum resistance furnace and measured using VarianMAT GD 150 and VG 3600 mass spectrometers at the National Taiwan University. Relevant analytical details can be found in $[31,32,46]$.

a Concordant date for low-temperature steps.

from $\sim 17$ to $13 \mathrm{Ma}$ (with $1 \sigma$ errors of $\pm 0.2 \sim 1.0$ Ma). In the plateau date calculation, ${ }^{39} \mathrm{Ar}$ gas fractions used were $>92 \%$ and the plateau dates obtained are all in excellent accordance with correlative intercept dates (Table 1). Amphibole and $\mathrm{K}$-feldspar separates from two mylonite samples (CHY-10 and -15) within the Puqu fault have more complicated age spectra, showing concaveshaped profiles with apparently older ages at high- and low-temperature steps, perhaps due to outgassing of impurities within the mineral separates and/or excess argon. Despite the complexity, the amphiboles yield acceptable plateaus, composed of $\sim 50 \%{ }^{39} \mathrm{Ar}$ extracted, which give ages of $16.9 \pm 0.2$ and $17.6 \pm 0.3 \mathrm{Ma}$ for CHY-10 and -15 , respectively (Fig. 2a,d). These plateau ages also agree with the correlative intercept dates (Table 1). Intermediate-temperature steps of the K-feldspars, composed of $\sim 20-30 \%{ }^{39} \mathrm{Ar}$ released, yield relatively younger but concordant dates of $11.7 \pm 0.1$ and $12.1 \pm 0.2 \mathrm{Ma}$, respectively (Fig. 2c,f). For these two mylonites, the ${ }^{40} \mathrm{Ar} /{ }^{39} \mathrm{Ar}$ dates of amphibole, biotite and K-feldspar vary systematically, i.e., decreasing in correspondence with the argon closure temperatures for different mineral phases that reduce from $\sim 550^{\circ} \mathrm{C}$ (hornblende) to $\sim 350^{\circ} \mathrm{C}$ (biotite) and $<300^{\circ} \mathrm{C}$ (K-feldspar) [19].

\section{Discussion}

\subsection{Timing of the Jiali faulting}

The eastern Gangdese Batholith is composed of several large granitoid complexes (Fig. 1a), which have been suggested to have been emplaced during $\sim 115-100 \mathrm{Ma}$ or earlier [17,20]. To better constrain the formation age of the Batholith, Lee et al. [21] performed single-grain U-Pb analyses on zircons from a sheared granite within the Parlung fault (\#73-97) and two undeformed granitoids located $\sim 10-60 \mathrm{~km}$ north of the Jiali shear zone, which yielded an age span of $\sim 136-113 \mathrm{Ma}$ 


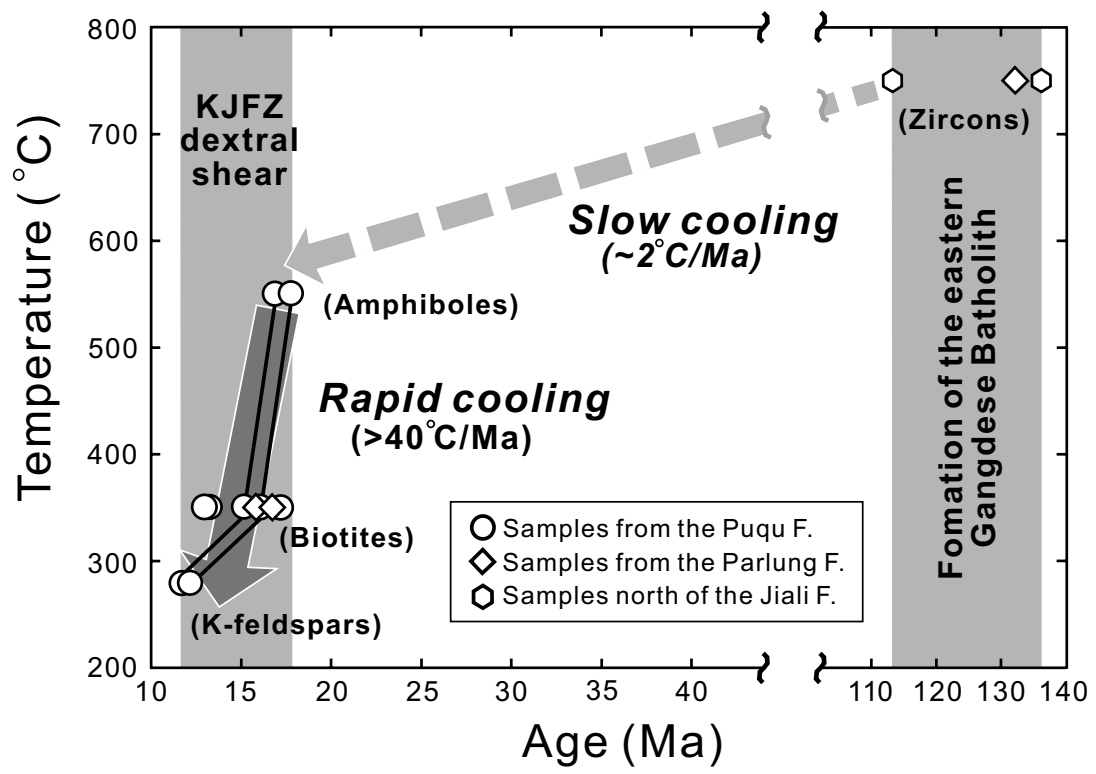

Fig. 3. Cooling paths of deformed granitic rocks from the Puqu and Parlung faults. Age data include ${ }^{40} \mathrm{Ar} /{ }^{39} \mathrm{Ar}$ dates for amphibole, biotite and K-feldspar (this study) and $\mathrm{U}-\mathrm{Pb}$ dates for zircon separates [21]. The closure temperatures are taken from [19]. Note that two zircon data points used to constrain the formation age of the eastern Gangdese Batholith are from the areas located in the north of the Jiali fault zone [21].

and corroborated early Cretaceous magmatic activity. These $\mathrm{U}-\mathrm{Pb}$ ages are significantly older than the ${ }^{40} \mathrm{Ar} /{ }^{39} \mathrm{Ar}$ dates obtained from the Puqu and Parlung faults (Fig. 2), but broadly coeval with or only slightly older than the ${ }^{40} \mathrm{Ar} /$ ${ }^{39}$ Ar plateau ages $(\sim 107-100 \mathrm{Ma})$ of hornblende and biotite separates from the undeformed granitoids that crop out in the north of the Jiali fault system [21]. From the $\mathrm{U}-\mathrm{Pb}$ and ${ }^{40} \mathrm{Ar} /{ }^{39} \mathrm{Ar}$ age information, a two-stage cooling history is deduced for the sheared granites within the Puqu and Parlung faults (Fig. 3). After the Cretaceous magmatic emplacement, these rocks experienced a very slow cooling $\left(\sim 2^{\circ} \mathrm{C} / \mathrm{Myr}\right)$ for the following $\sim 100 \mathrm{Myr}$, then underwent a very fast cooling ( $>40^{\circ} \mathrm{C} / \mathrm{Myr}$ ) during $\sim 18-12 \mathrm{Ma}$.

We interpret the fast, second-stage cooling as a localized event that recorded the timing of the main stage of right-lateral motion along the Jiali fault zone. The shearing, with a minor thrust component, deformed and exhumed the granitic rocks rapidly from $>550^{\circ} \mathrm{C}$ in the deeper crust to $<300^{\circ} \mathrm{C}$ at near surface levels. This is in contrast to the simple and modest cooling $\left(\sim 25^{\circ} \mathrm{Cl}\right.$
Myr) recorded in other parts of the eastern Gangdese Batholith, deduced from undeformed samples located in the north of the Jiali fault that are marked by Cretaceous U-Pb zircon $(\sim 136-113 \mathrm{Ma})$ and ${ }^{40} \mathrm{Ar} /{ }^{39} \mathrm{Ar}$ hornblende and biotite $(\sim 107-100 \mathrm{Ma})$ ages $[20,21]$. It is important to note that the proposed time span $(\sim 18-12$ Ma) for the Jiali dextral shearing overlaps with the period of the first stage $(\sim 17-13 \mathrm{Ma})$ of displacement along the Karakoram fault $[15,16]$. This coincidence strongly suggests that the entire KJFZ experienced a major phase of right-lateral motion around middle Miocene time. Hence, our observations not only corroborate the argument that regional dextral strike-slip movements in the Himalaya and southern Tibet started in the Miocene [22], but also indicate that the KJFZ activity took place synchronously with the north-southtrending normal faulting in the area that was most active during $\sim 18-13$ Ma [7,9]. Such synchronism implies a common causal mechanism for the KJFZ shearing and the normal faulting, the two most dominant tectonic events in southern Tibet. 


\subsection{Relation with the extension in southern Tibet}

Convective lithospheric thinning [1,2] is one of the popular models proposed to account for the plateau's uplift and east-west extension in Tibet, which may reflect the dissipation of potential energy in excess of what could be supported by the convergent forces. In the context of this model, the north-south-trending normal faults (or eastwest extension) and potassic magmatism, derived mainly from the continental lithospheric mantle [6,8], are interpreted as two surface manifestations that would occur coincidently. Thus, onset of these two events would record the time when the Tibetan plateau had reached its maximum elevation [2]. The suggested direct relationship between the east-west extension and the mantlederived potassic magmatism, as a response to convective lithospheric thinning [9], however, is not favored because (i) the potassic magmatism started at $\sim 25 \mathrm{Ma}$ [23], $\sim 7 \mathrm{Myr}$ earlier than the onset of the extension, (ii) the potassic magmatism ceased at $\sim 10 \mathrm{Ma}[6,24,25]$, in contrast to the extension that continued to the present, (iii) the occurrence of potassic magmatism is confined to the Lhasa Block, north of the Indus-Tsangpo suture [25], but the normal faults truncate the suture and extend southwards into the Tethyan Himalaya (Fig. 1b), and (iv) the KJFZ, as above described, associates temporally (and spatially) with the normal faults.

Another class of models attributes the eastwest extension to the accommodation of regional boundary forces such as principal strike-slip faulting, which could have been related to regional block extrusion $[3,4]$ or the underthrusting of the Indian lithosphere beneath Asia [10,11]. Under this framework, Armijo et al. [12] elaborated a model that invokes the right-lateral decoupling between northern Tibet and India to account for the formation of en echelon strike-slip segments of the KJFZ and the north-south-trending rifts in southern Tibet. By noting similarities with subduction at curved oceanic trenches such as the Sumatran, McCaffrey and Nabelek [10] also attributed the active tectonics in the Himalaya and southern Tibet to partitioning effects caused by oblique basal drag of the underthrust- ing Indian lithosphere. This underthrusting may have begun no sooner than $\sim 25 \mathrm{Ma}$ [25], when collision-thickened lithospheric mantle of the Lhasa Block was largely removed so that the more buoyant Indian lithospheric mantle [26,27] could start its northward moving [25]. The underthrusting of the Indian cratonic lithospheric mantle would have shut off the heat from the asthenosphere and eventually led to cessation of the potassic magmas produced by small degrees of melting in the remaining Lhasa lithospheric mantle [25]. If these scenarios are correct, the oblique convergence between India and Asia could have played a crucial role in developing the associated KJFZ dextral shearing and east-west extension since middle Miocene time. In this sense, the north-south-trending normal faults are more likely to represent crustal features whose initiation had little to do with the lithospheric mantle-derived potassic magmatism and thus are not proxies for the uplift of southern Tibet.

\subsection{Implications for Tibetan eastward extrusion}

Global positioning system (GPS) data [13] indicated that the northern part of the Tibetan plateau, bounded by the KJFZ in the south and by the Altyn Tagh and Kunlun faults in the north (Fig. 1), is currently moving eastward relative to both India and stable Eurasia. Our new ${ }^{40} \mathrm{Ar} /{ }^{39} \mathrm{Ar}$ data hence suggest that the eastward extrusion of northern Tibet began during $\sim 18-12 \mathrm{Ma}$, i.e., around middle Miocene time. This, in turn, implies that left-lateral motions of the Altyn Tagh and Kunlun faults were initiated about the same time if the concept of extrusional tectonics $[3,4]$ is applied. No general consensus on the magnitude of the dextral movement along the KJFZ has been reached. Whereas the overall offset of the Jiali fault has been estimated to approximate $450 \mathrm{~km}$ [12], the maximum offset of the Karakoram fault is likely to be only $\sim 120-150 \mathrm{~km}$ $[28,29]$. If we take the $\sim 450 \mathrm{~km}$ estimation, which seems consistent with the amount of spreading in the Andaman Sea when correlating the Jiali fault with the Sagaing fault (see below), the geological slip rate can be estimated as $\sim 35$ $26 \mathrm{~km} / \mathrm{Myr}$ (or $\mathrm{mm} / \mathrm{yr}$ ) for the eastern part of the 
KJFZ. Although this long-term average slip rate is about three times greater than that obtained from the Karakoram fault [16,28] in the west end of the KJFZ, it appears to correspond to, or is only slightly greater than, the present-day eastward extruding velocity of northern Tibet ( 26-21 mm/yr) inferred from GPS data [13]. An additional difficulty in the slip rate estimation is spasmodic movement along strike-slip faults. In the Karakoram fault, for example, the slip rate was the highest during $\sim 17-11 \mathrm{Ma}$, then became slower or even insignificant $[15,16]$. This is probably also the key reason why large variations exist in the slip rate estimation for different segments along the Altyn Tagh and Kunlun faults, especially when slip rates estimated from different temporal scales are compared [4]. To resolve these complexities, further more detailed studies on individual geologic features along the strike-slip fault zones and correlating them with the orogen-wide sense of Tibetan tectonics are urgently necessary.

Many investigators $[4,11,12,30]$ have argued to extend the Jiali fault southeastward to connect with the Red River shear zone. The latter, now moving dextrally, was shearing sinistrally during $\sim 27-17 \mathrm{Ma}[31,32]$, or even earlier [4,33], and was responsible for the southeastward extrusion of the Indochina relative to the South China blocks at that time period [3]. This correlation, however, is at odds with the GPS data [13], which suggest that the eastward extruding Tibetan block rotates and then moves southward (Fig. 1). Such a clockwise rotation of Tibetan extrusion has been repeatedly presumed by field surveys $[30,34]$, seismic analyses $[35,36]$ as well as other GPS measurements [37,38]. Hence, beyond the eastern margin of the Tibetan plateau, it appears to have had little eastward expulsion of crustal materials relative to South China [13]. A recent ${ }^{40} \mathrm{Ar} /{ }^{39} \mathrm{Ar}$ dating study along the Gaoligong fault [39] indicated that this important yet previously poorly acknowledged shear zone experienced a main phase of right-lateral displacement during $\sim 18-13 \mathrm{Ma}$. The information allows us to correlate it with the Parlung fault, and to correlate the Puqu fault with the Kumon and then Sagaing faults (Fig. 1a). ${ }^{40} \mathrm{Ar} /{ }^{39} \mathrm{Ar}$ dates $[40,41]$ for sheared rocks in the Sagaing fault delineate a broadly coeval duration $(\sim 20-15 \mathrm{Ma})$ of motion for this right-lateral boundary fault system, which is generally accepted to have played a key role in opening of the Andaman Sea beginning 15-10 Ma [42]. These age constraints together delineate a Miocene deformation record for the regional dextral accommodation zone [34], which extends southward from the eastern Himalayan Syntaxis down to the Andaman Sea (Fig. 1) and developed in response to the continuing northward indentation of India into Asia.

\section{Concluding remarks}

New ${ }^{40} \mathrm{Ar} /{ }^{39} \mathrm{Ar}$ results from the Jiali fault allow us to propose that the entire $\mathrm{KJFZ}$ was initiated and most active during $\sim 18-12 \mathrm{Ma}$. Therefore, the eastward extrusion of northern Tibet along the KJFZ in the south, and along the Altyn Tagh and Kunlun fault zones in the north, started around middle Miocene time. The Tibetan eastward expulsion, however, did not propagate much across the eastern margin of the plateau but may have been largely accommodated by the block's internal deformation [13] associated with clockwise rotation around the eastern Himalayan Syntaxis, a process that should also have begun in the middle Miocene. The southward extruding block is bounded by the right-lateral Jiali, Gaoligong and Sagaing faults in the west and by the leftlateral Xianshuihe, Xiaojiang and Dien Bien Phu faults in the east (Fig. 1). This hypothesis is consistent with the time constraint from the Xianshuihe fault, which has been active sinistrally since at least $\sim 12 \mathrm{Ma}$ [43]. Such an extrusion process could have not only reactivated the Red River shear zone, so it evolved afterward as a dextral fault, but also accounted for the bending of its northwestern segment in the Ailao Shan area, Yunnan (Fig. 1). The block extrusion may have continued further southward to Myanmar and Thailand [13], leading to changes in the sense of minor strike-slip fault movement [44] affiliated with the late Cenozoic deformation in this part of southeast Asia. 


\section{Acknowledgements}

We thank Q. Zhang, Y.-Z. Wang and Q. Qian for their help with field trips to Tibet and Yunnan, Z.-x. Li and E. Wang for helpful discussion at various stages of this study. Insightful journal reviews provided by K.K. Min and M. Searle were of significant help in clarifying several points of this paper. This work benefited from financial supports by the National Science Council, Taiwan, ROC.[RV]

\section{References}

[1] G.A. Houseman, D.P. McKenzie, P. Molnar, Convective instability of a thickened boundary layer and its relevance for the thermal evolution of continental convergence belts, J. Geophys. Res. 86 (1981) 6115-6132.

[2] P. Molnar, P.C. England, J. Martinod, Mantle dynamics, the uplift of Tibetan plateau, and the Indian monsoon, Rev. Geophys. 31 (1993) 357-396.

[3] P. Tapponnier, G. Peltzer, R. Armijo, A.Y. Le Dain, P. Cobbold, Propagating extrusion tectonics in Asia - new insights from simple experiments with plasticine, Geology 10 (1982) 611-616.

[4] P. Tapponnier, Z. Xu, F. Roger, B. Meyer, N. Arnaul, G. Wittlinger, J. Yang, Oblique stepwise rise and growth of the Tibet plateau, Science 294 (2001) 1671-1677.

[5] R. Armijo, P. Tapponnier, J.L. Mercier, T.-L. Han, Quaternary extension in southern Tibet: Field observations and tectonic implications, J. Geophys. Res. 91 (1986) 13803-13872S.

[6] S. Turner, C.J. Hawkesworth, J. Liu, N. Rogers, S. Kelly, P. van Calsteren, Timing of Tibetan uplift constrained by analysis of volcanic rocks, Nature 364 (1993) 50-54.

[7] M.E. Coleman, K.P. Hodges, Evidence for Tibetan plateau uplift before $14 \mathrm{Myr}$ ago from a new minimum estimate of east-west extension, Nature 374 (1995) 49-52.

[8] S.-L. Chung, C.-H. Lo, T.-Y. Lee, Y. Zhang, Y. Xie, X.H. Li, K.-L. Wang, P.-L. Wang, Diachronous uplift of the Tibetan plateau starting $40 \mathrm{Myr}$ ago, Nature 394 (1998) 769-773.

[9] H. Williams, S. Turner, S. Kelley, N. Harris, Age and composition of dikes in southern Tibet: New constraints on the timing of east-west extension and its relationship to postcollisional magmatism, Geology 29 (2001) 339-342.

[10] R. McCaffrey, J. Nabelek, Role of oblique convergence in the active deformation of the Himalayas and southern Tibet plateau, Geology 26 (1998) 691-694.

[11] A. Yin, T.M. Harrison, Geologic evolution of the Himalayan-Tibetan orogen, Annu. Rev. Earth Planet. Sci. 28 (2000) 211-280.

[12] R. Armijo, P. Tapponnier, T.-L. Han, Late Cenozoic right-lateral faulting in southern Tibet, J. Geophys. Res. 94 (1989) 2787-2838.

[13] Q. Wang, P.-Z. Zhang, J.T. Freymueller, R. Bilham, K.M. Larson, X. Lai, X. You, Z. Niu, J. Wu, Y. Li, J. Liu, Z. Yang, Q. Chen, Present-day crustal deformation in China constrained by global positioning system measurements, Science 294 (2001) 574-577.

[14] P. Molnar, Q. Deng, Faulting associated with large earthquakes and the average rate of deformation in central and eastern Asia, J. Geophys. Res. 89 (1984) 6203-6227.

[15] W.J. Dunlap, R.F. Weinberg, M.P. Searle, Karakoram fault zone rocks cool in two phases, J. Geol. Soc. London 155 (1998) 903-912.

[16] M.P. Searle, R.F. Weinberg, W.J. Dunlap, Transpressional tectonics along the Karakoram fault zone, northern Ladakh: Constraints on Tibetan extrusion, in: R.E. Holdsworth, R.A. Strachan, J.F. Dewey (Eds.), Continental Transpressional and Transtensional Tectonics, Geol. Soc. London Spec. Publ. 135 (1998) 307-325.

[17] Bureau of Geology and Mineral Resources of Xizang Autonomous Region, Regional Geology of Xizang (Tibet), with 1/1,500,000 Geological Map, Geological Publishing House, Beijing, 1993.

[18] H.-Y. Lee, Unpublished data, 2002.

[19] I. McDougall, T.M. Harrison, Geochronology and Thermochronology by the ${ }^{40} \mathrm{Ar} /{ }^{39} \mathrm{Ar}$ Method, Oxford University Press, Oxford, 1988, 212 pp.

[20] J.-R. Wang, Uplift History of the Southern Tibetan Plateau (The Lhasa Block): Constrained by Thermochronological Data, MSc Thesis, Nationall Taiwan University, Taipei, 1997, 138 pp.

[21] H.-Y. Lee, S.-L. Chung, D.-J. Wen, Y. Zhang, Y. Xie, J.-R. Wang, T.F. Yang, C.-H. Lo, T.-Y. Lee, H. Li, New geochronological data from the eastern Gangdese batholith with implications for the dextral movement of the Jiali fault, J. Conf. Abst. 6 (2001) 331.

[22] A. Pecher, J.-L. Bouchez, P. LeFort, Miocene dextral shearing between Himalaya and Tibet, Geology 19 (1991) 683-685.

[23] C. Miller, R. Schuster, U. Klötzli, W. Frank, F. Purtscheller, Post-collisional potassic and ultrapotassic magmatism in SW Tibet: Geochemical and $\mathrm{Sr}-\mathrm{Nd}-\mathrm{Pb}-\mathrm{O}$ isotopic constraints for mantle source characteristics and petrogenesis, J. Petrol. 40 (1999) 1399-1424.

[24] C. Coulon, H. Maluski, C. Bollinger, S. Wang, Mesozoic and Cenozoic volcanic rocks from central and southern Tibet: ${ }^{39} \mathrm{Ar} /{ }^{40} \mathrm{Ar}$ dating, petrological characteristics and geodynamical significance, Earth Planet. Sci. Lett. 79 (1986) 281-302.

[25] S.-L. Chung, M.-F. Chu, C.-H. Lo, Y. Zhang, Y. Xie, X.-H. Li, T.-Y. Lee, C.-Y. Lan, Q. Zhang, Y. Wang, Tibetan plateau evolution inferred from spatial and temporal variations in post-collisional magmatism, Earth Planet. Sci. Lett. (2003) in prep.

[26] T.J. Owens, G. Zandt, Implications of crustal property variations for models of Tibetan plateau evolution, Nature 387 (1997) 37-43. 
[27] G. Kosarev, R. Kind, S.V. Sobolev, X. Yuan, W. Hanka, S. Oreshin, Seismic evidence for a detached Indian lithospheric mantle beneath Tibet, Science 283 (1998) 13061309.

[28] M.P. Searle, Geological evidence against large-scale preHolocene offsets along the Karakoram Fault: Implications for the limited extrusion of the Tibetan plateau, Tectonics 15 (1996) 171-186.

[29] M.A. Murphy, A. Yin, R. Kapp, T.M. Harrison, L. Ding, J. Guo, Southward propagation of the Karakoram fault system, southwest Tibet: Timing and magnitude of slip, Geology 28 (2000) 451-454.

[30] L. Ratschbacher, W. Frisch, C. Chen, G. Pan, Cenozoic deformation, rotation, and stress patterns in eastern Tibet and western Sichuan, China, in: A. Yin, T.M. Harrison (Eds.), The Tectonic Evolution of Asia, Cambridge University Press, Cambridge, 1996, pp. 227-249.

[31] P.-L. Wang, C.-H. Lo, T.-Y. Lee, S.-L. Chung, C.-Y. Lan, N.T. Yem, Thermochronological evidence for the movement of the Ailao Shan-Red River shear zone: A perspective from Vietnam, Geology 26 (1998) 887-890.

[32] P.-L. Wang, C.-H. Lo, S.-L. Chung, T.-Y. Lee, C.-Y. Lan, T.V. Thang, Onset of the movement along the Ailao Shan-Red River shear zone: Constraints from ${ }^{40} \mathrm{Ar} /{ }^{39} \mathrm{Ar}$ dating results for Nam Dinh area, northern Vietnam, J. Asian Earth Sci. 18 (2000) 85-96.

[33] P.H. Leloup, N. Arnaud, R. Lacassin, J.R. Kienast, T.M. Harrison, T.P. Trinh, A. Replumaz, P. Tapponnier, New constraints on the structure, thermochronology, and timing of the Ailao Shan-Red River shear zone, SE Asia, J. Geophys. Res. 106 (2001) 6683-6732.

[34] E. Wang, B.C. Burchfiel, L.H. Royden, L. Chen, J. Chen, W. Li, Z. Chen, The late Cenozoic Xianshuihe-Xiaojiang, Red River, and Dali fault systems of southwestern Sichuan and central Yunnan, China, Geol. Soc. Am. Spec. Paper 327 (1998) 108 pp.

[35] W.E. Holt, J.F. Ni, T.C. Wallace, A.J. Haines, The active tectonics of the eastern Himalayan Syntaxis and surrounding regions, J. Geophys. Res. 96 (1991) 1459514632.

[36] W.E. Holt, Correlated crust and mantle strain fields in Tibet, Geology 28 (2000) 67-70.

[37] R.W. King, F. Shen, B.C. Burchfiel, L.H. Royden, E. Wang, Z. Chen, Y. Liu, X.-Y. Zhang, J.-X. Zhao, Y.
$\mathrm{Li}$, Geodetic measurement of crustal motion in southwest China, Geology 25 (1997) 179-182.

[38] W.E. Holt, N. Chamot-Rooke, X. Le Pichon, A.J. Haines, B. Shen-Tu, J. Ren, Velocity field in Asia inferred from Quaternary fault slip rates and global positioning system observations, J. Geophys. Res. 105 (2000) 19185 19209.

[39] F.-J. Hsu, ${ }^{40} \mathrm{Ar} /{ }^{39} \mathrm{Ar}$ Thermochronological Study of the Gaoligong Shan Shear Zone in Western Yunnan Province, MSc Thesis, National Taiwan University, Taipei, 2000, 86 pp.

[40] G. Bertrand, C. Rangin, H. Maluski, T.A. Han, M. Thien, O. Myint, W. Maw, S. Lwin, Cenozoic metamorphism along the Shan scarp (Myanmar): Evidence for ductile shear along the Sagaing fault or northward migration of the eastern Himalayan syntaxis?, Geophys. Res. Lett. 26 (1999) 915-918.

[41] G. Bertrand, C. Rangin, H. Maluski, H. Bellon, GIAC Scientific Party, Diachronous cooling along the Mogok metamorphic belt (Shan scarp, Myanmar): The trace of the northward migration of the Indian syntaxis, J. Asian Earth Sci. 19 (2001) 649-659.

[42] C. Rangin, N. Chamot-Rooke, C. Nielsen, F. Farcy, D. Sun, E. Bourdon, Pull-apart basin history along the eastern Indian shear zone from Eocene to Present, J. Conf. Abst. 6 (2001) 326.

[43] F. Roger, S. Calassou, J. Lancelot, J. Malavieille, M. Mattauer, Z. Xu, Z. Hao, L. Hou, Miocene emplacement and deformation of the Konga Shan granite (Xianshui He fault zone, western Sichuan, China): Geodynamical implications, Earth Planet. Sci. Lett. 130 (1995) 201-216.

[44] R. Lacassin, H. Maluski, P.H. Leloup, P. Tapponnier, C. Hinthong, K. Siribhakdi, S. Chuaviroj, A. Charoenravat, Tertiary diachronic extrusion and deformation of western Indochina: Structural and ${ }^{40} \mathrm{Ar} /{ }^{39} \mathrm{Ar}$ evidence from NW Thailand, J. Geophys. Res. 102 (1997) 10013-10037.

[45] P.R. Renne, C.C. Swister, A.L. Deino, D.B. Karner, T.L. Owens, D.J. DePaolo, Intercalibration of standards, absolute ages and uncertainties in ${ }^{40} \mathrm{Ar} /{ }^{39} \mathrm{Ar}$ dating, Chem. Geol. 145 (1998) 117-152.

[46] C.-H. Lo, S.-L. Chung, T.-Y. Lee, G. Wu, Age of the Emeishan flood magmatism and relations to Permian-Triassic boundary events, Earth Planet. Sci. Lett. 198 (2002) $449-458$. 